\title{
Evaluation of different plant extracts for effective management of fungal rot of tomato and brinjal in Kashmir Valley
}

\section{Jahangir Abdullah Koka*, Abdul Hamid Wani and Mohd Yaqub Bhat}

University of Kashmir. Department of Botany. Section of Mycology and Plant Pathology. Srinagar. India. *Email: kokajahangir76@gmail.com.

\begin{abstract}
The aim of present research was focused on the antifungal activities of Prunella vulgaris $\mathrm{L}$ and Paeonia suffruticosa Andrews via in vitro approach through agar well diffusion assay at three concentrations $(25 \mu \mathrm{L}, 50 \mu \mathrm{L}$ and $75 \mu \mathrm{L})$ against fungi causing diseases in tomato and brinjal. All the concentration of plant extracts showed antimycotic activity against tested pathogenic fungi. Antimycotic activity increased with the increased concentrations of plant extracts. However, higher concentrations proved more effective than lower concentrations. It was revealed from the present study that the ethanolic and aqueous extracts of Prunella vulgaris L showed maximum antimycotic activity against Rhizoctonia solani and least inhibitory effect against Penicillium chrysogenum. It was further revealed from the present study that the ethanolic extract of Paeonia suffruticosa Andrews showed maximum antimycotic activity against Penicillium expansum and least activity against Mucor plumbeus. Whereas the aqueous extract of Paeonia suffruticosa Andrews showed maximum antimycotic activity against Rhizoctonia solani and Penicllium expansum and least inhibitory effect against Mucor plumbeus.
\end{abstract}

Keywords: Antifungal activity; Rot causing fungi; Concentration; Plant extracts; Agar Well Diffusion.
Received

February 28, 2020

Accepted

August 28, 2020

Released

August 31, 2020

Full Text Article

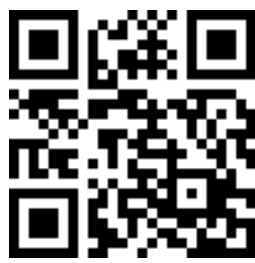

ORCID

(D) 0000-0003-0040-1624 Jahangir Abdullah Koka

D) 0000-0002-6157-9656 Abdul Hamid Wani

(D) 0000-0002-0582-4813

Mohd Yaqub Bhat

\section{Introduction}

Almost, all plants are attacked by a number of plant pathogenic fungi resulting in many plant diseases which reduce their yield and quality of the products. Fungal rots are world-wide in occurrence and have been reported from all parts of the world (Janisiewicz and Korsten, 2002).The destructive pathogen causing rots on tomato is present in parts of 
the country where moisture is plentiful and temperatures are moderate to favour their development (Sokhi and Sohi, 1982). Various workers have isolated and identified a diverse range of fungal pathogens belonging to the genera Alternaria, Aspergillus, Rhizopus, Mucor, Penicillium, Phoma, Fusarium, causing rot diseases of various fruits and vegetables (Snowdon, 1990; Jones, 1991; Iqbal et al., 2003; Mari et al., 2003; Patel et al., 2005; Ali et al., 2005; Ebele, 2011; Taskeen-un-Nisa et al., 2011; Abata et al., 2016; Wennekar et al., 2017).

Various biocontrol fungi and extracts obtained from many medicinal plants have gained much popularity and scientific interest for their antifungal and antibacterial activities (Santas et al., 2010; Parveen et al., 2016a; Koka et al., 2017). Plant extracts are believed to be more acceptable and less hazardous than synthetic compounds and can be therefore used as an alternative to synthetic antifungal chemicals (Nazzaro et al., 2000).

Several control strategies have been employed by agricultural scientists to minimize the losses caused by pathogenic fungi. In this study, the important medicinal plants Prunella vulgaris and Paeonia suffruticosa have been evaluated for their antifungal activity. Medicinal plants are the only affordable and accessible source of primary health care for many people in Asia, especially in absence of access to modern medical facilities. Most of the compounds extracted from these plants, used as pharmaceuticals, agrochemicals, flavour and fragrance ingredients, food additives and pesticides. Amin et al. (2013) studied the medicinal importance of variety of pharmacologically active compounds including quinones, triterpenoids, flavonoids, isoflavonoids and stilbene glycosides.

The aim of this present study is to investigate the antifungal activities of ethanolic and aqueous extracts of leaves of Prunella vulgaris L and Paeonia suffruticosa Andrews.

\section{Materials and methods}

\section{Plant collection and identification}

The fresh plant material of Prunella vulgaris L and Paeonia suffruticosa Andrews were collected from District Baramulla and Kashmir University Botanical Garden (KUBG), Srinagar. The authenticity of the plant was confirmed in Plant Taxonomy Department of Botany University of Kashmir. Adequate amount of the leaves of these plants were collected in polythene bags, brought to laboratory for evaluating their antimycotic activity under in vitro conditions.

\section{Preparation of plant extracts}

These plant leaves in a required quantity were sundried for 24 hours and then milled into powder using morter and pestle. About $20 \mathrm{~g}$ of coarsely powdered leaves $(20 \mathrm{~g} / 100 \mathrm{~mL})$ were extracted separately in a soxhlet extractor for 8 to 10 hours $\left(30{ }^{\circ} \mathrm{C}\right.$ $50^{\circ} \mathrm{C}$ ) sequentially with ethanol and water separately in order to extract non-polar and polar compounds (Elgorashi et al., 2004).

\section{Preparation of inoculums of fungi}

Pure fungal cultures of Penicillium expansum, Aspergillus niger, Alternaria alternata, Mucor plumbeus, Penicillium chrysogenum, Trichothecium roseum and Rhizoctonia solani were obtained from Plant Pathology and Mycology Laboratory, Department of Botany University of Kashmir. These pure cultures were grown on Potato dextrose agar (PDA) medium at $27{ }^{\circ} \mathrm{C} \pm 1{ }^{\circ} \mathrm{C}$ in Petri plates. Spores of the each fungal species were collected from these cultures after 7 days (Broekaert et al., 1990). 


\section{Antifungal activity}

The antifungal activity of the plant extracts was determined by agar well diffusion method as adopted by Perez et al. (1990), Alzoreky et al. (2003) and Ahmad et al. (2012). Seven day old fungal cultures grown on PDA medium were used to assess the antifungal activity of selected plant extracts. An aliquot of $100 \mu \mathrm{L}$ inoculum from each fungal species was inoculated in $20 \mathrm{~mL}$ of molten SDA medium in culture tubes. The culture tubes were then homogenised manually and poured into $90 \mathrm{~mm}$ Petri plate. The culture plates were allowed to solidify inside the laminar airflow chamber and three wells at periphery of each Petri plate were made using sterile cork borers of $5 \mathrm{~mm}$ in diameter. A $2 \mathrm{mg} / \mathrm{mL}$ stock solution was made from the plant extract and then different volumes $(25 \mu \mathrm{L}, 50 \mu \mathrm{L}$ and $75 \mu \mathrm{L}$ ) from that stock solution were loaded to respective wells. Hexaconazole solution $(20 \mu \mathrm{L} /$ well) was used as control in the separate well in the same petri plate. The effect of plant extracts on different rot causing fungi were evaluated and the plates were then sealed and incubated at $25{ }^{\circ} \mathrm{C} \pm 2{ }^{\circ} \mathrm{C}$ for $4-5$ days. Three replicates were made for each treatment. Antifungal potential was calculated by measuring inhibition zone diameters in millimeters (mm) with the help of standard measuring scale (Norrel and Messley 1997).

\section{Statistical analysis}

The data collected during these investigations were subjected to appropriate statistical analysis using SPSS statistical software (version 16.0). The data was statistically analyzed by one way analysis of variance (ANOVA) and comparison of the means was done by Duncan multiple comparison tests at $\mathrm{P} \leq 0.05$.Standard deviation was calculated as $\delta=\sqrt{\frac{\sum x^{2}}{N-1}}$.

\section{Results}

\section{Effect of leaf extracts of Prunellla vulgaris $L$ on the zone of mycelial inhibition of some rot causing fungi}

It was found from the results (Table 1, Figure 1) that the ethanolic leaf extract of Prunella vulgaris $\mathrm{L}$. caused maximum inhibitory activity of mycelial growth at $25 \mu \mathrm{L}, 50 \mu \mathrm{L}$ and $75 \mu \mathrm{L}$ concentrations with zone of inhibition of $22.66 \mathrm{~mm}, 24.33 \mathrm{~mm}$ and $26.00 \mathrm{~mm}$ against Rhizoctonia solani, respectively. The inhibition in zone of mycelial growth of Aspergillus niger and Alternaria alternata was $20.00 \mathrm{~mm}, 22.00 \mathrm{~mm}, 23.66 \mathrm{~mm}$ and $16.33 \mathrm{~mm}, 19.00 \mathrm{~mm}, 23.33 \mathrm{~mm}$ due to leaf extracts of $P$. vulgaris at $25 \mu \mathrm{L}, 50 \mu \mathrm{L}$ and $75 \mu \mathrm{L}$ concentrations, respectively. The moderate inhibitory activity of ethanolic extract was found against Penicillium expansum with zone of mycelial inhibition of $16.00 \mathrm{~mm}$, $19.00 \mathrm{~mm}, 22.00 \mathrm{~mm}$, respectively, and against Trichothecium roseum with zone of mycelial inhibition of $15.66 \mathrm{~mm}, 17.00 \mathrm{~mm}, 21.00 \mathrm{~mm}$ at $25 \mu \mathrm{L}, 50 \mu \mathrm{L}$ and $75 \mu \mathrm{L}$, respectively. However, the inhibition in mycelial growth of Mucor plumbeus was $14.33 \mathrm{~mm}, 16.00 \mathrm{~mm}, 19.00 \mathrm{~mm}$ at $25 \mu \mathrm{L}, 50 \mu \mathrm{L}$ and $75 \mu \mathrm{L}$ concentrations of plant extracts of P. vulgaris. Whereas least inhibitory activity was shown against Penicillium chrysogenum with zone of inhibition as $13.00 \mathrm{~mm}, 16.33 \mathrm{~mm}$ and $18.33 \mathrm{~mm}$ at $25 \mu \mathrm{L}$, $50 \mu \mathrm{L}$ and $75 \mu \mathrm{L}$ of ethanolic leaf extracts.

Further, it was observed from results (Table 2, Figure 2) that the aqueous extract of Prunella vulgaris L. showed maximum inhibitory activity in mycelial growth against Rhizoctonia solani at $25 \mu \mathrm{L}, 50 \mu \mathrm{L}$ and $75 \mu \mathrm{L}$ concentrations with zone of inhibition of $20.33 \mathrm{~mm}, 22.66 \mathrm{~mm}$ and $24.66 \mathrm{~mm}$, respectively. Moderate antifungal activity of leaf extract was recorded against Aspergillus niger with zone of mycelial inhibition of $18.00 \mathrm{~mm}, 20.00 \mathrm{~mm}, 21.66 \mathrm{~mm}$, against Alternaria alternata with zone of mycelial inhibition of $14.33 \mathrm{~mm}, 17.33 \mathrm{~mm}, 20.66 \mathrm{~mm}$ and against Penicillium expansum with zone of mycelial inhibition of $13.00 \mathrm{~mm}, 16.00 \mathrm{~mm}, 19.33 \mathrm{~mm}$ at $25 \mu \mathrm{L}, 50 \mu \mathrm{L}$ and $75 \mu \mathrm{L}$ 
concentrations of leaf extracts, respectively. The inhibition in mycelial growth of Mucor plumbeus and Trichothecium roseum was observed as $12.33 \mathrm{~mm}, 15.33 \mathrm{~mm}, 17.00 \mathrm{~mm}$ and $11.66 \mathrm{~mm}, 15.00 \mathrm{~mm}, 19.00 \mathrm{~mm}$ at $25 \mu \mathrm{L}, 50 \mu \mathrm{L}$ and $75 \mu \mathrm{L}$ concentrations of leaf extracts of $P$. vulgaris, respectively. The least mycelial inhibition found in Penicillium chrysogenum was as $11.00 \mathrm{~mm}, 13.33 \mathrm{~mm}$ and $16.00 \mathrm{~mm}$ at $25 \mu \mathrm{L}, 50 \mu \mathrm{L}$ and $75 \mu \mathrm{L}$ concentrations, respectively.

Table 1. Effect of ethanolic leaf extracts of Prunella vulgaris L.at different concentrations on the zone of mycelial inhibition of some rot causing fungi.

\begin{tabular}{|l|c|c|c|c|}
\hline \multirow{2}{*}{$\begin{array}{l}\text { Fungal } \\
\text { Pathogens }\end{array}$} & \multicolumn{4}{|c|}{ Zone of mycelial inhibition (mm) } \\
\cline { 2 - 5 } & $\mathbf{2 5} \boldsymbol{\mu \mathbf { L }}$ & $\mathbf{5 0} \boldsymbol{\mu \mathbf { L }}$ & $\mathbf{7 5} \boldsymbol{\mu \mathbf { L }}$ & \multirow{2}{*}{ Control } \\
\hline Penicillium expansum & $16.00 \pm 1.00^{\mathrm{d}}$ & $19.00 \pm 1.00^{\mathrm{c}}$ & $22.00 \pm 1.00^{\mathrm{b}}$ & $24.33 \pm 0.57^{\mathrm{a}}$ \\
\hline Aspergillus niger & $20.00 \pm 1.00^{\mathrm{c}}$ & $22.00 \pm 1.00^{\mathrm{b}}$ & $23.66 \pm 1.15^{\mathrm{b}}$ & $27.00 \pm 1.00^{\mathrm{a}}$ \\
\hline Alternaria alternata & $16.33 \pm 0.57^{\mathrm{d}}$ & $19.00 \pm 1.00^{\mathrm{c}}$ & $23.33 \pm 0.57^{\mathrm{b}}$ & $25.00 \pm 1.00^{\mathrm{a}}$ \\
\hline Mucor plumbeus & $14.33 \pm 0.57^{\mathrm{c}}$ & $16.00 \pm 1.00^{\mathrm{c}}$ & $19.00 \pm 1.00^{\mathrm{b}}$ & $22.00 \pm 1.00^{\mathrm{a}}$ \\
\hline Penicillium chrysogenum & $13.00 \pm 1.00^{\mathrm{d}}$ & $16.33 \pm 0.57^{\mathrm{c}}$ & $18.33 \pm 0.57^{\mathrm{b}}$ & $21.33 \pm 0.57^{\mathrm{a}}$ \\
\hline Trichothecium roseum & $15.66 \pm 0.57^{\mathrm{c}}$ & $17.00 \pm 1.00^{\mathrm{c}}$ & $21.00 \pm 1.00^{\mathrm{b}}$ & $24.00 \pm 1.00^{\mathrm{a}}$ \\
\hline Rhizoctonia solani & $22.66 \pm 0.57^{\mathrm{c}}$ & $24.33 \pm 0.57^{\mathrm{b}}$ & $26.00 \pm 1.00^{\mathrm{a}}$ & $27.00 \pm 1.00^{\mathrm{a}}$ \\
\hline
\end{tabular}

Each value is mean of 3 replicates \pm SD. Mean values followed by different superscript in a column are significantly different $(\mathrm{p} \leq 0.05)$.

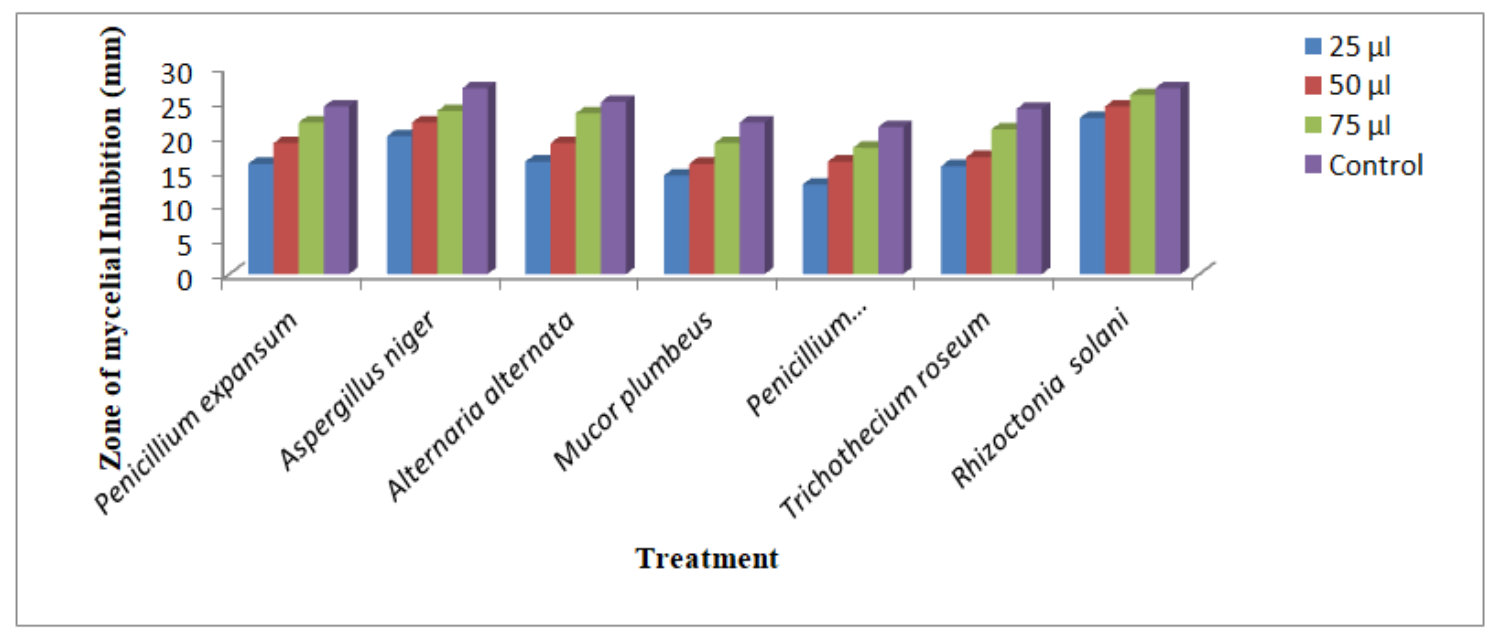

Figure 1. Effect of ethanolic leaf extracts of Prunella vulgaris L. at different concentrations on the zone of mycelial inhibition of some rot causing fungi. 
Table 2. Effect of aqueous leaf extracts of Prunella vulgaris L. at different concentrations on the zone of mycelial inhibition of some rot causing fungi.

\begin{tabular}{|l|c|c|c|c|}
\hline \multirow{2}{*}{$\begin{array}{l}\text { Concentration } \\
\text { Pangal }\end{array}$} & \multicolumn{3}{|c|}{ Zone of mycelial inhibition (mm) } \\
\cline { 2 - 5 } & $\mathbf{2 5} \boldsymbol{\mu L}$ & $\mathbf{5 0} \boldsymbol{\mu L}$ & $\mathbf{7 5} \boldsymbol{\mu L}$ & \multirow{2}{*}{ Control } \\
\hline Penicillium expansum & $13.00 \pm 1.00^{\mathrm{d}}$ & $16.00 \pm 1.00^{\mathrm{c}}$ & $19.33 \pm 0.57^{\mathrm{b}}$ & $22.00 \pm 1.00^{\mathrm{a}}$ \\
\hline Aspergillus niger & $18.00 \pm 1.00^{\mathrm{c}}$ & $20.00 \pm 1.00^{\mathrm{b}}$ & $21.66 \pm 1.15^{\mathrm{b}}$ & $23.00 \pm 1.00^{\mathrm{a}}$ \\
\hline Alternaria alternata & $14.33 \pm 0.57^{\mathrm{d}}$ & $17.33 \pm 0.57^{\mathrm{c}}$ & $20.66 \pm 0.57^{\mathrm{b}}$ & $22.00 \pm 1.00^{\mathrm{a}}$ \\
\hline Mucor plumbeus & $12.33 \pm 0.57^{\mathrm{d}}$ & $15.33 \pm 0.57^{\mathrm{c}}$ & $17.00 \pm 1.00^{\mathrm{b}}$ & $19.33 \pm 0.57^{\mathrm{a}}$ \\
\hline Penicillium chrysogenum & $11.00 \pm 1.00^{\mathrm{d}}$ & $13.33 \pm 0.57^{\mathrm{c}}$ & $16.00 \pm 1.00^{\mathrm{b}}$ & $18.00 \pm 1.00^{\mathrm{a}}$ \\
\hline Trichothecium roseum & $11.66 \pm 0.57^{\mathrm{d}}$ & $15.00 \pm 1.00^{\mathrm{c}}$ & $19.00 \pm 1.00^{\mathrm{b}}$ & $22.00 \pm 1.00^{\mathrm{a}}$ \\
\hline Rhizoctonia solani & $20.33 \pm 0.57^{\mathrm{d}}$ & $22.66 \pm 0.57^{\mathrm{c}}$ & $24.66 \pm 0.57^{\mathrm{b}}$ & $26.00 \pm 1.00^{\mathrm{a}}$ \\
\hline
\end{tabular}

Each value is mean of 3 replicates \pm SD. Mean values followed by different superscript in a column are significantly different $(\mathrm{p} \leq 0.05)$

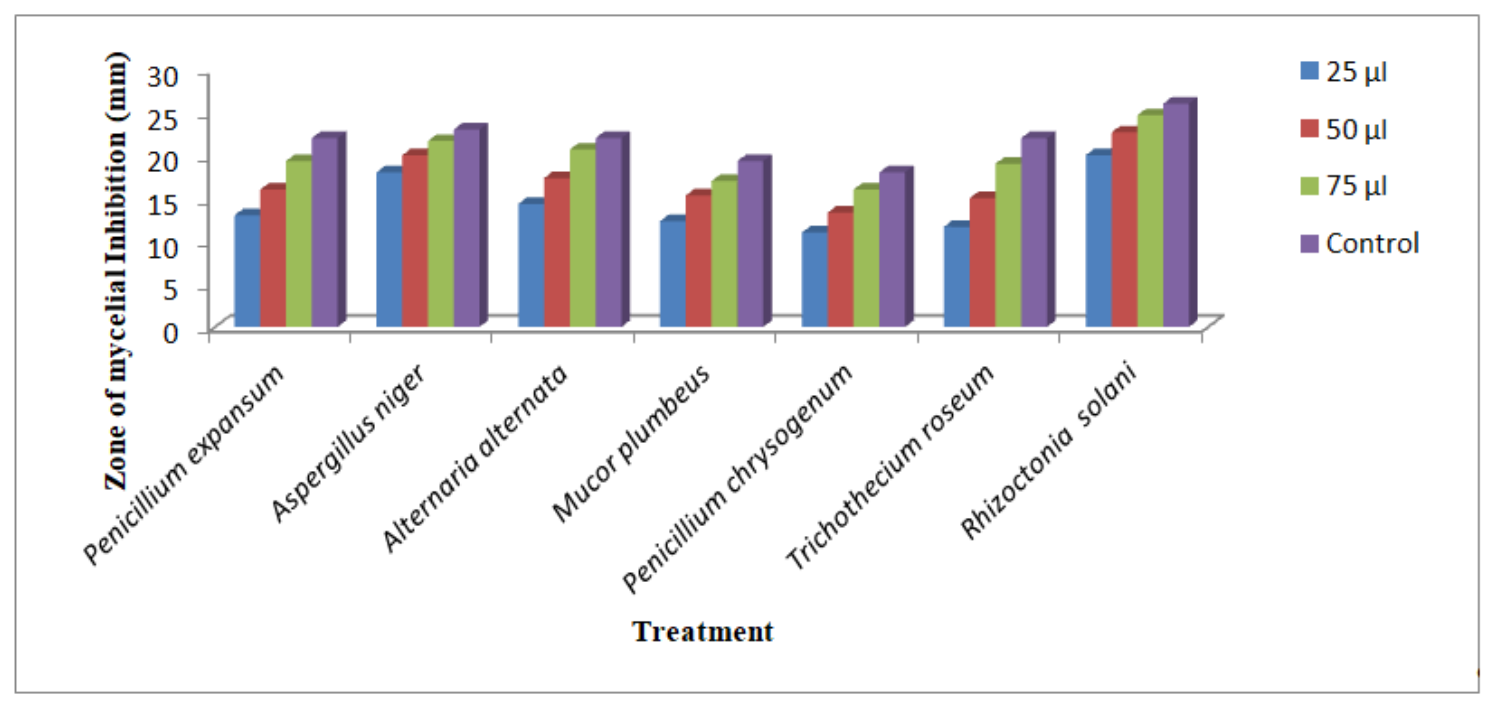

Figure 2. Effect of aqueous leaf extracts of Prunella vulgaris L. at different concentrations on the zone of mycelial inhibition of some rot causing fungi.

\footnotetext{
Effect of leaf extracts of Paeonia suffruticosa Andrews at different concentrations on the zone of mycelial inhibition of some rot causing fungi.

It was revealed from results (Table 3, Figure 3) that the ethanolic leaf extract of Paeonia suffruticosa Andrews showed maximum inhibitory activity at $25 \mu \mathrm{L}, 50 \mu \mathrm{L}$ and $75 \mu \mathrm{L}$ concentrations with zone of mycelial inhibition of $23.00 \mathrm{~mm}, 25.00 \mathrm{~mm}$ and $26.66 \mathrm{~mm}$ against Penicillium expansum, respectively. The inhibition in mycelial growth of Rhizoctonia solani and Alternaria alternata was $22.33 \mathrm{~mm}, 25.00 \mathrm{~mm}, 28.33 \mathrm{~mm}$ and 21.00 $\mathrm{mm}, 24.00 \mathrm{~mm}, 26.00 \mathrm{~mm}$ at $25 \mu \mathrm{L}, 50 \mu \mathrm{L}$ and $75 \mu \mathrm{L}$ concentrations of ethanolic leaf extracts of $P$. suffruticosa, respectively. The inhibition in mycelial growth of Aspergillus niger was $21.33 \mathrm{~mm}, 23.00 \mathrm{~mm}, 25.00 \mathrm{~mm}$ at $25 \mu \mathrm{L}, 50 \mu \mathrm{L}$ and $75 \mu \mathrm{L}$ concentrations of ethanolic leaf extracts of $P$. suffruticosa, respectively. The moderate antifungal activity of ethanolic extract was shown against Penicillium chrysogenum and Trichothecium roseum with zone of mycelial inhibition as $20.00 \mathrm{~mm}, 21.66 \mathrm{~mm}, 24.00 \mathrm{~mm}$ and $19.33 \mathrm{~mm}$, $22.00 \mathrm{~mm}, 25.00 \mathrm{~mm}$ at $25 \mu \mathrm{L}, 50 \mu \mathrm{L}$ and $75 \mu \mathrm{L}$ concentrations of leaf extracts, respectively. The least inhibition in mycelial growth was found in case of Mucor plumbeus
} 
with zone of inhibition as $19.66 \mathrm{~mm}, 22.00 \mathrm{~mm}$ and $24.33 \mathrm{~mm}$ at $25 \mu \mathrm{L}, 50 \mu \mathrm{L}$ and $75 \mu \mathrm{L}$ concentrations respectively of ethanolic leaf extracts of $P$. suffruticosa.

Further it was found from the results (Table 4, Figure 4) that the aqueous extract of Paeonia suffruticosa Andrews showed maximum inhibitory activity at $25 \mu \mathrm{L}, 50 \mu \mathrm{L}$ and $75 \mu \mathrm{L}$ concentrations with zone of mycelial inhibition of $20.66 \mathrm{~mm}, 23.33 \mathrm{~mm}, 25.33 \mathrm{~mm}$ and $19.33 \mathrm{~mm}, 21.33 \mathrm{~mm}, 25.00 \mathrm{~mm}$ against Rhizoctonia solani and Penicillium expansum respectively. The aqueous leaf extract of Paeonia suffruticosa showed moderate antifungal activity against Alternaria alternata and Aspergillus niger with the zone of mycelial inhibition as $19.00 \mathrm{~mm}, 22.00 \mathrm{~mm}, 24.33$ and $19.00 \mathrm{~mm}, 21.00 \mathrm{~mm}, 23.33 \mathrm{~mm}$ at $25 \mu \mathrm{L}$, $50 \mu \mathrm{L}$ and $75 \mu \mathrm{L}$ concentrations respectively. However, the zone of inhibition in mycelial growth of Trichothecium roseum and Penicillium chrysogenum was $19.00 \mathrm{~mm}, 20.66 \mathrm{~mm}$, $23.33 \mathrm{~mm}$ and $18.00 \mathrm{~mm}, 19.66 \mathrm{~mm}, 22.33 \mathrm{~mm}$ at $25 \mu \mathrm{L}, 50 \mu \mathrm{L}$ and $75 \mu \mathrm{L}$ concentrations of leaf extracts respectively. Whereas the least mycelial inhibition was shown in Mucor plumbeus with the zone of inhibition as $17.66 \mathrm{~mm}, 20.00 \mathrm{~mm}$ and $23.33 \mathrm{~mm}$ at $25 \mu \mathrm{L}$, $50 \mu \mathrm{L}$ and $75 \mu \mathrm{L}$, respectively of leaf extracts.

Table 3. Effect of ethanolic leaf extracts of Paeonia suffruticosa Andrews at different concentrations on the zone of mycelial inhibition of some rot causing fungi.

\begin{tabular}{|l|c|c|c|c|}
\hline \multirow{2}{*}{$\begin{array}{l}\text { Fungal } \\
\text { Pathogens }\end{array}$} & \multicolumn{3}{|c|}{ Zone of mycelial inhibition (mm) } \\
\cline { 2 - 5 } & $\mathbf{2 5} \boldsymbol{\mu L}$ & $\mathbf{5 0} \boldsymbol{\mu L}$ & $\mathbf{7 5} \boldsymbol{\mu L}$ & \multirow{2}{*}{ Control } \\
\hline Penicillium expansum & $23.00 \pm 1.00^{\mathrm{c}}$ & $25.00 \pm 1.00^{\mathrm{b}}$ & $26.66 \pm 1.15^{\mathrm{b}}$ & $30.00 \pm 1.00^{\mathrm{a}}$ \\
\hline Aspergillus niger & $21.33 \pm 0.57^{\mathrm{c}}$ & $23.00 \pm 1.00^{\mathrm{c}}$ & $25.00 \pm 1.00^{\mathrm{b}}$ & $29.00 \pm 1.00^{\mathrm{a}}$ \\
\hline Alternaria alternata & $21.00 \pm 1.00^{\mathrm{d}}$ & $24.00 \pm 1.00^{\mathrm{c}}$ & $26.00 \pm 1.00^{\mathrm{b}}$ & $28.33 \pm 0.57^{\mathrm{a}}$ \\
\hline Mucor plumbeus & $19.66 \pm 1.15^{\mathrm{d}}$ & $22.00 \pm 1.00^{\mathrm{c}}$ & $24.33 \pm 1.00^{\mathrm{b}}$ & $27.00 \pm 1.00^{\mathrm{a}}$ \\
\hline Penicillium chrysogenum & $20.00 \pm 1.00^{\mathrm{c}}$ & $21.66 \pm 1.15^{\mathrm{c}}$ & $24.00 \pm 1.00^{\mathrm{b}}$ & $27.00 \pm 1.00^{\mathrm{a}}$ \\
\hline Trichothecium roseum & $19.33 \pm 0.57^{\mathrm{d}}$ & $22.00 \pm 1.00^{\mathrm{c}}$ & $25.00 \pm 1.00^{\mathrm{b}}$ & $30.00 \pm 1.00^{\mathrm{a}}$ \\
\hline Rhizoctonia solani & $22.33 \pm 0.57^{\mathrm{d}}$ & $25.00 \pm 1.00^{\mathrm{c}}$ & $28.33 \pm 0.57^{\mathrm{b}}$ & $30.33 \pm 1.00^{\mathrm{a}}$ \\
\hline
\end{tabular}

Each value is mean of 3 replicates \pm SD. Mean values followed by different superscript in a column are significantly different $(\mathrm{p} \leq 0.05)$.

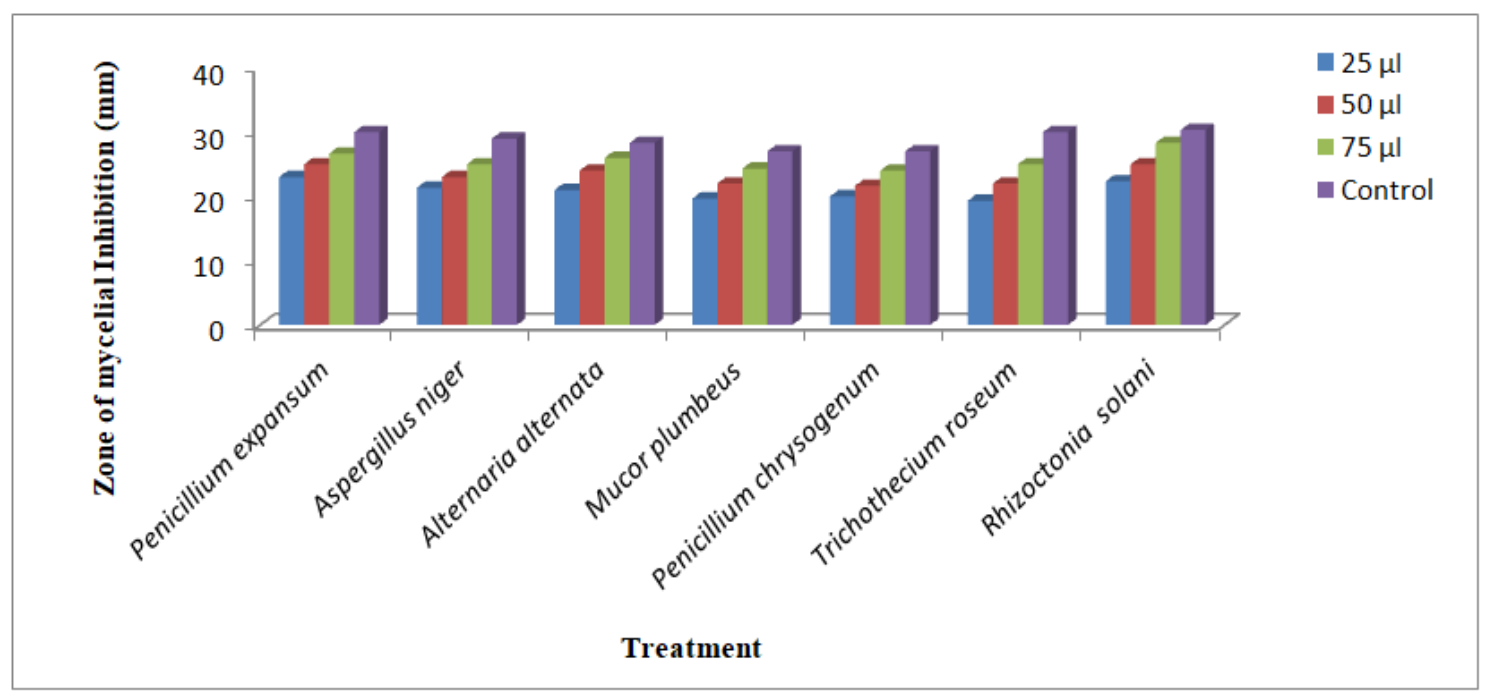

Figure 3. Effect of ethanolic leaf extracts of Paeonia suffruticosa Andrews at different concentration on the zone of mycelial inhibition of some rot causing fungi. 
Table 4. Effect of aqueous leaf extracts of Paeonia suffruticosa Andrews at different concentration on the zone of mycelial inhibition of some rot causing fungi.

\begin{tabular}{|l|c|c|c|c|}
\hline \multirow{2}{*}{$\begin{array}{l}\text { Concentration } \\
\text { Fungal } \\
\text { Pathogens }\end{array}$} & \multicolumn{4}{|c|}{ Zone of mycelial inhibition (mm) } \\
\cline { 2 - 5 } & $\mathbf{2 5} \boldsymbol{\mu \mathbf { L }}$ & $\mathbf{5 0} \boldsymbol{\mu \mathbf { L }}$ & $\mathbf{7 5} \boldsymbol{\mu \mathbf { L }}$ & \multicolumn{1}{c|}{ Control } \\
\hline Penicillium expansum & $19.33 \pm 0.57^{\mathrm{d}}$ & $21.33 \pm 0.57^{\mathrm{c}}$ & $25.00 \pm 1.00^{\mathrm{b}}$ & $27.00 \pm 1.00^{\mathrm{a}}$ \\
\hline Aspergillus niger & $19.00 \pm 1.00^{\mathrm{d}}$ & $21.00 \pm 1.00^{\mathrm{c}}$ & $23.33 \pm 0.57^{\mathrm{b}}$ & $26.00 \pm 1.00^{\mathrm{a}}$ \\
\hline Alternaria alternata & $19.00 \pm 1.00^{\mathrm{d}}$ & $22.00 \pm 1.00^{\mathrm{c}}$ & $24.33 \pm 0.57^{\mathrm{b}}$ & $26.33 \pm 0.57^{\mathrm{a}}$ \\
\hline Mucor plumbeus & $17.66 \pm 1.15^{\mathrm{c}}$ & $20.00 \pm 1.00^{\mathrm{b}}$ & $23.33 \pm 1.15^{\mathrm{a}}$ & $25.00 \pm 1.00^{\mathrm{a}}$ \\
\hline Penicillium chrysogenum & $18.00 \pm 1.00^{\mathrm{c}}$ & $19.66 \pm 1.15^{\mathrm{c}}$ & $22.33 \pm 0.57^{\mathrm{b}}$ & $25.00 \pm 1.00^{\mathrm{a}}$ \\
\hline Trichothecium roseum & $19.00 \pm 1.00^{\mathrm{c}}$ & $20.66 \pm 1.15^{\mathrm{c}}$ & $23.33 \pm 0.57^{\mathrm{b}}$ & $26.00 \pm 1.00^{\mathrm{a}}$ \\
\hline Rhizoctonia solani & $20.66 \pm 1.52^{\mathrm{d}}$ & $23.33 \pm 0.57^{\mathrm{c}}$ & $25.33 \pm 0.57^{\mathrm{b}}$ & $27.66 \pm 0.57^{\mathrm{a}}$ \\
\hline
\end{tabular}

Each value is mean of 3 replicates \pm SD. Mean values followed by different superscript in a column are significantly different $(\mathrm{p} \leq 0.05)$.

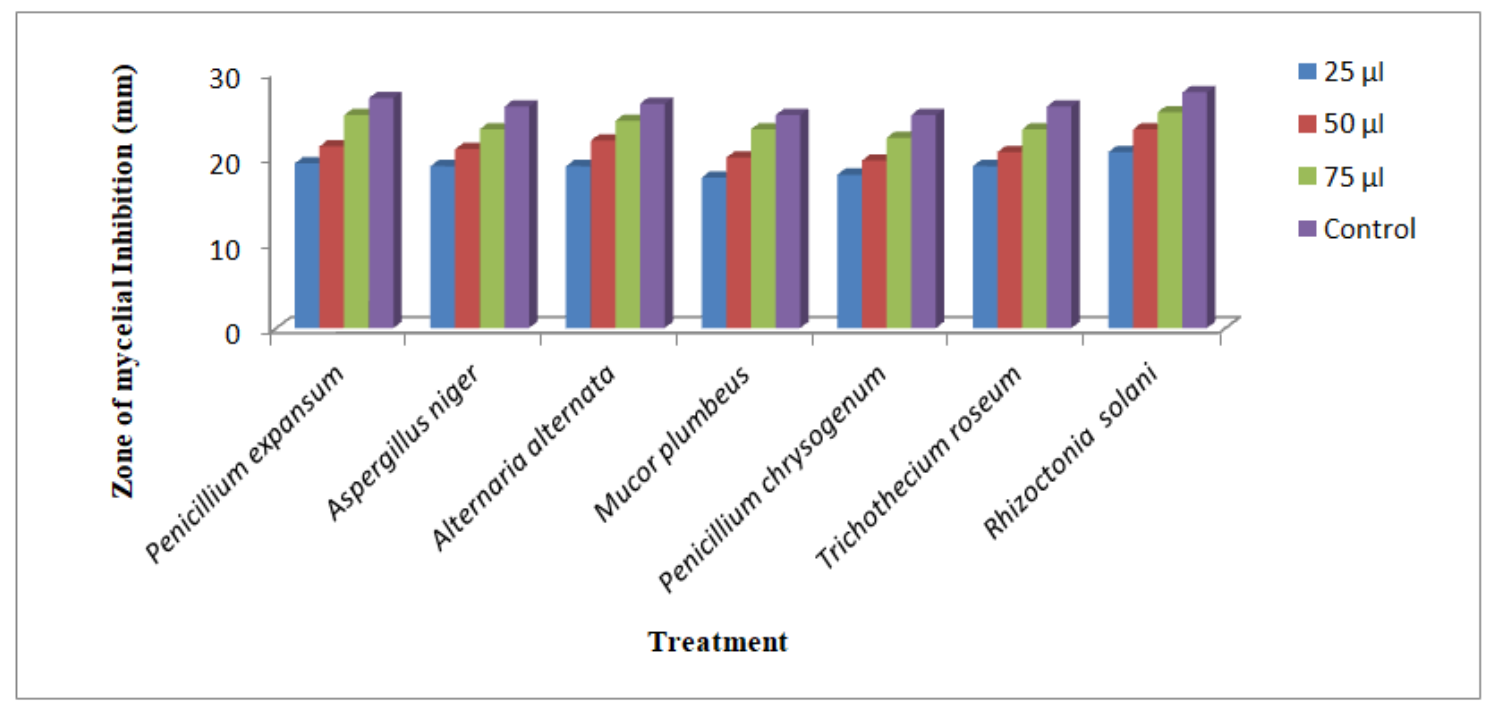

Figure 4. Effect of aqueous leaf extracts of Paeonia suffruticosa Andrews at different concentrations on the zone of mycelial inhibition of some rot causing fungi.

\section{Discussion}

It was clear from the results that extracts of two medicinal plants Prunella vulgaris and Paeonia suffruticosa brought about significant inhibition in the mycelial growth at their different concentration. Higher concentration proved effective than lower concentration. In the present study some plant extracts were evaluated for their antimycotic activity against the fungus causing rot of tomato and brinjal. These two test plant species proved highly effective in reducing the mycelial growth of fungi causing rot diseases of tomato and brinjal fruits. Such study has been carried for the first time on the extracts of Prunella vulgaris and Paeonia suffruticosa. However, extracts of other plants have been evaluated for their antimycotic activity in a similar way. In a similar study, efficacy of plant extract of Maesa lanceolata, var. goulungensis against many fungal plant pathogens such as Phytophthora cryptogea, Trichoderma virens, Aspergillus niger, Phoma sp., Fusarium oxysporium, Pythium ultimum, Cochliobolus heterostrophus, Rhizoctonia solani, Sclerotium rolfsii and Pyrenophora teres under in vitro conditions was reported by 
Okemo et al. (2003). Abass (2007) studied the effect of leaf extracts of Henna Lawsonia inermis at different concenterations on some plant pathogenic fungi namely Rhizoctonia solani, Thielaviopsis paradoxa, Fusarium oxysporum f. sp. melonis and Mauginiella scaettae. Several workers tested the antifungal activity of aqueous, ethyl alcohol and acetone extracts of Garlic Allium sativum L., onion Allium cepa L., leek Allium porrum L., Ocimum basilicum L. and Allium sativum L. against Aspergillus niger, Colletotrichum gloeosporioides and other different fungi (Misra and Dixit, 1976; Irkin and Korukluoglu, 2007; Ogbebor et al., 2007). Webster et al. (2008) screened 14 plants for their antifungal activity against various pathogenic fungi and concluded that Fragaria virginiana, Epilobium angustifolium and Potentilla simplex show a promising antifungal potential. Baka (2010) reported the antifungal activity of six medicinal plants Amaranthus spinosus, Barbeya oleoides, Clutia lanceolata, Lavandula pubescens, Maerua oblongifolia and Withania somnifera against five plant pathogenic fungi A. brassicae, A. solani, Botrytis fabae, Fusarium solani and Phytophthora infestans. Activity of extracts obtained from nine herbaceous species, viz. Borago officinalis, Orobanche crenata, Plantago lanceolata, Plantago coronopus, Sanguisorba minor, Silene vulgaris, Sonchus asper, Sonchus oleraceus and Taraxacum officinale, were tested against some postharvest fungal rot causing pathogens Monilinia laxa, Botrytis cinerea, Penicillium expansum, Penicillium digitatum, Penicillium italicum, Aspergillus carbonarius and Aspergillus niger under in vitro and in vivo conditions (Gatto et al., 2011).

\section{Conclusion}

The present study indicates that the inhibitory effect of plant extracts which have been evaluated for the first time on these rot causing fungi in Kashmir may be attributed to the presence of some partially effective antifungal ingredients, in the plant extracts of all the test plants and thus may have potential to be used as the new natural fungicide for the management of fungal rot diseases.

\section{Acknowledgement}

The authors are thankful to the Head, Department of Botany, University of Kashmir, Hazratbal, Srinagar for providing necessary help and facilities during the course of the study.

\section{Conflicts of interest}

Authors declare that they do not own any conflicts of interest.

\section{References}

Abata, L. K.; Paz, I. A.; Viera, W.; Flores, F. J. First report of Alternaria rot caused by Alternaria alternata on peach in Ecuador. Plant Disease, v. 100, no 11, p.2323, 2016. https://doi.org/10.1094/PDIS-03-16-0318-PDN

Abass, M. H. Study antifungal activity of Henna leaves (Lawsonia inermis) extracts on some plant pathogenic fungi. The Agriculture Informative Magazine of Dumshik University, v. 23, p. 113-125, 2007.

Ahmad, N.; Amir, M. K.; Ayaz, S.; Ahmad, J. A. Antimicrobial profile of the selected medicinal plants. International Journal of Chemical and Life Sciences, v. 1, p.1039-1041, 2012. 
Ali, S.; Rivera, V. V.; Secor, G. A. First report of Fusarium gramincearum causing dry rot of potato in North Dakota. Plant Disease, v.89, p. 105, 2005. https://doi.org/10.1094/PD89-0105B

Alzoreky, N. S.; Nakahara, K. Antibacterial activity of extracts from some edible plants commonly consumed in Asia. International Journal of Food Microbiology, v. 80, p. 223-230, 2003.

Amin, A.; Wani, S. H.; Mokhdomi, T. A.; Bukhari, S.; Wafai, A. H.; Mir, J. I.; Hassan, Q. P.; Qadri, R. A. Investigating the pharmacological potential of Iris kashmiriana in limiting growth of epithelial tumors. Pharmacognosy Journal, v. 5, no. 4, p. 170-175, 2013. https://doi.org/10.1016/j. phcgj.2013.07.003

Baka, Z. A. M. Antifungal activity of six Saudi medicinal plant extracts against five phyopathogenic fungi. Archives of Phytopathology and Plant Protetion, v. 43, p. 736-743, 2010. https://doi.org/10.1080/03235400802144595

Broekaert, W. F.; Terras, F. R. G.; Cammue, B. P. A.; Vanderleyden, J. An automated quantative assay for fungal growth inhibition. FEMS Microbiology Letters, v. 69, p. 55-60, 1990. https://doi.org/10.1111/j.1574-6968.1990.tb04174.x

Ebele, M. I. Evaluation of some aqueous plant extracts used in the control of pawpaw (Carica papaya L.) fruits rot fungi. Journal of Applied Biosciences, v. 37, p. 2419-2424, 2011

Elgorashi, E. E.; Van Staden, J. Pharmacological screening of six Amaryllidaceae species. Journal of Ethnopharmacology, v. 90, p. 27-32, 2004.

Gatoo, M. A.; Ippolito, A.; Linsalata, V.; Cascarano, N. A.; Nigro, F.; Vanadia, S.; Venere, D. D. Activity of extracts from wild edible herbs against postharvest fungal diseases of fruits and vegetables. Postharvest Biology and Technology, v. 61, p. 72-82, 2011.

Iqbal, S. M.; Ghafoor, Z. A.; Haqqani. Pathogenicity and fungicidal efficacy for Sclerotinia rot of brinjal. International Journal of Agricultural and Biological Engineering, v. 5, no 4, p. 618-620, 2003.

Irkin, R.; Korukluoglu, M. Control of Aspergillus niger with garlic, onion and leak extracts. Africian Journal of Biotechnology, v. 6, no. 4, p. 384-387, 2007.

Janisiewicz, W. J.; Korsten, L. Biological control of postharvest diseases of fruits. Annual Review of Phytopathology, v. 40, p. 411-441, 2002.

Jones, J. P. Early blight. In: Jones, J. P. (Eds.). Compendium of tomato diseases. St. Paul, MN: APS Press, 1991.

Mari, M.; Bertolini, P.; Pratella, G. C. Non-conventional methods for the control of postharvest pear diseases. Journal of Applied Microbiology, v.94, p.761-766, 2003.

Misra, S. B.; Dixit, S. N. Fungicidal spectrum of the leaf extract of Allium sativum. Indian Phytopathology, v. 29, p. 448-449, 1976.

Nazzaro, F.; Fratianni, F.; Coppola, R.; De Feo, V. Essential oils and antifungal activity. Pharmaceuticals, v. 10, no. 4, 86, 2017. https://doi.org/10.3390/ph10040086

Norrel, S. A.; Messley, K. E. Microbiology laboratory manual: Principles and applications. New Jersey: Prentice Hall, 1997.

Ogbebor, N. O.; Adekunle, A. T.; Enobakhare, D. A. Inhibition of Colletotrichum gloeosporioides (Penz.) Sacc. causal organism of rubber (Hevea brasiliensis Muell.-Arg.) leaf spot using plant extracts. African Journal of Biotechnology, v. 6, p. 213-218, 2007. 
Okemo, P. O.; Bais, H. P.; Vivanco, J. M. In vitro activities of Maesa lanceolata extracts against fungal plant pathogens. Fitoterapia, v. 74, p. 312-316, 2003.

Patel, N. A.; Dange, S. R. S.; Patel, S. I. Efficacy of chemicals in controlling fruit rot of tomato caused by Alternaria tomato. Indian Journal of Agricultural Research, v. 39, p. 72-75, 2005.

Perez, C.; Pauli, M.; Bazerque, P. An antibiotic assay by the well agar method. Acta Biologiae et Medicinae Experimentalis, v. 15, p. 113-115, 1990.

Snowdon, A. L. A colour atlas of post-harvest diseases and disorders of fruits and vegetables. London: Wolfe Scientific, 1990. v. 1.

Snowdon, A. L. A colour atlas of post-harvest diseases and disorders of fruits and vegetables. Aylesbury, England: Vegetables BPCC Hazel Books, 1990. v. 2.

Sokhi, S. S.; Sohi, H. S. Assessment of losses in tomato caused by buckeye rot. Indian Phytopathology, v.35, p. 675-676, 1982.

Taskeen-un-Nisa.; Wani, A. H.; Mir, R. A. Fusarium rot of tomato and its management in Kashmir. Journal of Plant Disease Sciences, v. 6, no. 2, p. 107-113, 2011.

Taskeen-un-Nisa.; Wani, A. H.; Bhat, M. Y.; Pala, S. A.; Mir, R. A. In vitro inhibitory effect of fungicides and botanicals on mycelial growth and spore germination of Fusarium oxysporum. Journal of Biopesticides, v. 4, no. 1, p. 53-56, 2011.

Webster, D.; Taschereau, P.; Belland, R. J.; Sand, C.; Rennie, R. P. Antifungal activity of medicinal plant extracts; preliminary screening studies. Journal of Ethnopharmacology, v. 115, p. 140-146, 2008.

Wenneker, M.; Pham, K. T. K.; Lemmers, M. E. C.; Deboer, F. A.; Van Leeuwen, P. J.; Hollinger, T. C.; Thomma, B. P. H. J. Fibulorhizoctonia psychrophila is the causal agent of lenticel spot on apple and pear fruit in Netherlands. European Journal of Plant Pathology, v. 148, no. 1, p. 213-217, 2017.

License information: This is an open-access article distributed under the terms of the Creative Commons Attribution License, which permits unrestricted use, distribution, and reproduction in any medium, provided the original work is properly cited. 